Research Article

\title{
ETHNOBOTANICAL AND ETHNOVETERINARY IMPORTANCE OF PLANTS OF SCRUB AREAS OF DACHIGAM NATIONAL PARK, JAMMU AND KASHMIR, INDIA
}

\author{
ARIF YAQOOB MALIK ${ }^{1 *}$, D.P SINGH \\ ${ }^{1}$ Department of Environmental Science BBA, Central University, Lucknow, Uttar Pradesh, India. Email: arifmalikenv@gmail.com
}

Received: 30 March 2015, Revised and Accepted: 28 December 2018

ABSTRACT

Objective: The rich plant diversity of mountains has been used by the indigenous people for thousands of years as health-care remedies. A study on the important plant communities of scrub ecosystems of Dachigam National Park was carried out with the special aim of enlisting the ethnobotanical, and ethnoveterinary uses of plants being used by the people of the area.

Methods: Data were collected by visual appraisal approach, rapid rural approach, and questionnaire methods coupled with group meetings and field discussions.

Results: Data collected from the present investigation indicate that 59 plants belonging to 33 families with Rosaceae, the dominant family, were exclusively used for ethnobotanical purposes and 10 plant species belonging to 8 families were having ethnoveterinary use. These species include 14 medicinal species, 10 vegetable species, 10 with edible species, 6 fodder species, 6 species used as tea substitutes, 3 species for menstrual problems, 3 species used for religious ceremonies, 2 species used for chutney, 2 art and craft species, and 1 species used for ornamental, fuelwood, and agricultural tools each.

Conclusion: The people of the area are exclusively dependent on medicinal plants using traditional knowledge that provides them with the best therapeutic and economic benefits. Such traditional knowledge could be valuable for developing local and regional conservation strategies for these fragile ecosystems. There is an urgent need to thoroughly analyze the secondary metabolite properties of such plants to validate their authenticity in the local health-care systems.

Keywords: Ethnobotany, Ethnoveterinary, Diversity, Traditional knowledge, Open scrub.

(c) 2019 The Authors. Published by Innovare Academic Sciences Pvt Ltd. This is an open access article under the CC BY license (http://creativecommons. org/licenses/by/4. 0/) DOI: http://dx.doi.org/10.22159/ajpcr.2019.v12i3.5591

\section{INTRODUCTION}

Traditional knowledge is a cultural asset which can be used for the recognition and preservation of valuable species as well as habitats in long-term management [1,2]. Ethnobotany is one of the precious cultural heritages of an area that involves the interaction between plants and people and foremost among these are the traditional use of medicinal plants and sustainable management of plant biodiversity by these indigenous communities [1]. The recent gradual shift to natural medicine worldwide has also highlighted the importance of compiling information about medicinal plant species used by ethnic and indigenous communities [3,4]. A plant that possesses therapeutic properties naturally synthesizes and accumulates some secondary metabolites such as alkaloids, glycosides, volatile oils, vitamins, and minerals in different body parts such as leaves, fruits, seeds, and rhizome [5,6] and possesses a special importance in these mountain ecosystems [7]. These plants play a significant role in providing health care and improving the economy of the country [8].

As increased market demand for herbal medicine and recent controversies regarding biopiracy, such documentation and compilation of ethnoecological knowledge are of top priority $[9,10]$. Moreover, integrating traditional knowledge is gaining importance in many parts of the world [11] and people having long-term associations with vegetation can provide a valuable observation [12] for conservation and management plans for vegetation of these ecosystems that give food security to indigenous as well as people of low lands [13,14]. Apart from plants being social and ecological indicators when employed together with traditional knowledge can play a significant role in conservation strategy designing [15]. Ethnoecological knowledge if supplemented with the latest scientific insights can provide new dimensions of sustainable development that environmentally, economically, and socially acceptable and effective tools against the scenario of climate change and economic instability [16].

Since not many studies have been carried out to document the ethnobotanical uses of plants growing in the Kashmir Himalaya $[17,18]$ especially on scrub ecosystems, so the current study was undertaken to prepare an ethnobotanical inventory of the plant resources of the study area that will prove to be beneficial for both traditional communities and for sustainable utilization of biodiversity.

\section{METHODS}

Study area

Dachigam National Park is located within the heart of Kashmir Himalaya located at the North West tip of the Himalayan biodiversity hotspot. the study was carried out from January to December 2014.

\section{Ethnobotanical survey}

Regular trips were made on a monthly basis throughout the year in different altitudinal zones using visual appraisal approach, rapid rural appraisal, and questionnaire to compile information about different aspects of plants such as local name, local uses, part used, method of collection, collection time, mode of administration, curative properties, and method of preparation. In general, the respondents were elderly people especially women, local vaids and herbal healers in the neighborhood of the study area. About 150 households and 51 vaids and herbal healers were interviewed, and the information was documented through a questionnaire. In addition, the pastoralists migrating to the area during summer for grazing were also contacted and interviewed about the plant resources they use during their stay in the area. 


\section{RESULTS AND DISCUSSION}

The scrub area is a rich abode of medicinal plants which are decreasing day by day due to increasing biotic pressures such as deforestation, grazing, unregulated collection, and overexploitation by pastoralists. Although the thorny and prickly species are resistant to grazing pressures, rest of the herbs are sensitive to it. Species such as Berberis lyceum and Artemisia scoparia were present in most of the areas while as Podophyllum hexandrum, Iris hookriana, Bergenia ciliata, Sassurea lappa, and Dioscorea deltoids were reported a few places of the study area with Dryopteris balanfordii and Adiantum cappilus-veneris being restricted to moist locations.

The study revealed that the scrub ecosystem harbors a diverse plant wealth valuable for ethnoecological knowledge (Tables 1 and 2). The present investigation reveals that 59 species (including 14 medicinal species, 10 vegetable species, 10 with edible species, 6 fodder species, 6 species used as tea substitutes, 3 species for menstrual problems, 3 species used for religious ceremonies, 2 species used for chutney, 2 art and craft species, and 1 species used for ornamental, fuelwood, and agricultural tools each) belonging to 33 families are exclusively being used by locals for ethnobotanical purposes while as 10 species belonging to 8 families are used for treating livestock ailments. Most of the species are having more than one local use. Our study confirms that the scrub vegetation offers valuable ecosystem services to ethnic groups of the region. The questionnaire and RAA analyses indicate that the inhabitants of Kashmir Himalaya possess prized knowledge about the local plant biodiversity and the services that it provides are significantly important to them. The plant species are utilized by the ethnic groups as per their traditional knowledge. Different plant parts such as leaves, roots, seeds, flowers, and rhizome are used to cure common human ailments while a few others are either used to treat livestock diseases or used as cosmetic substitutes [19]. The absence of market, poverty and climatic constraints make the ethnic groups chiefly dependent on many different species to supplement their diet in terms of vegetables and wild edibles [20].

Among the species the edible fruits of B. lyceum, Elaeagnus spp., Frageria nubicola, Prunus prostrata, Rosa webbiana, Rubus fruticosus, Rubus ellipticus, Viburnum grandiflorum, and Ziziphus jajuba are eaten especially by the young children who provide a continuous supply of essential minerals and nutrients to them. For species such as Taraxicum officinale, Malva neglecta, Rumex acetosa, Polygonum plebeum, Oxalis corniculata, and Plantigo major, fresh and tender leaves are collected washed and cooked as vegetables and for others such as Dipsacus innermis and R. webbiana the leaves are dried and are cooked as vegetables. While in few species such as Hypericum perforatum and Sibbaldia cuneata leaves are used and for Viola odorata and Viola betanosifolia flowers are used for preparing local tea. Similarly, Thymus linearis is used to add flavors to various dishes and for preparation of Achar a local pickle. The utilization of these wild species for consumption by these communities clearly indicates the dependence of their food habits on wild species. Species such as D. deltoids, Verbascum thapsus, Plectranthus rugosa, Ajuga parviflora, and Geranium wallichianum are also used in case of livestock to treat different troubles such as open wounds, indigestion, gas bowls, throat infection, swelling, and inflammation of hooves and Silene vulgare is used to improve milk production in cows while Asparagus filicinus is used to ensure easy delivery in cattle and sheep.

As most of the herb species are sensitive to grazing and harvesting; their existence in the community may provide a significant indication of the presence of other keystone species such as thorny and prickly shrub species that provide (nurse effect) conducive habitat for such herbs [21]. Plants provide food, fodder, fiber, medicines, etc., and these global resources are used ruthlessly especially in Kashmir Himalaya where the quality, as well as quantity of such resources, is deteriorating more rapidly [22].

Table 1: Ethnobotanical uses of plants

\begin{tabular}{|c|c|c|c|c|}
\hline Species & Local name & Family & Part used & Name of the disease/other medicinal importance \\
\hline Adiantum capilus veneris & Gew theer & Pteridaceae & Leaves & $\begin{array}{l}\text { Leaves are boiled in water with sugar and the decoction is used } \\
\text { for the treatment of prolonged asthma and chest congestion }\end{array}$ \\
\hline Artemisia absinthium & Tethwen & Asteraceae & Shoot & $\begin{array}{l}\text { Extract from shoot mixed with water taken orally to treat } \\
\text { uneven menstrual cycles }\end{array}$ \\
\hline Artemisia maritiama & Tethwen & Asteraceae & Leaves & $\begin{array}{l}\text { Leaf extract is used as a digestive tonic and in treating } \\
\text { intermittent fever }\end{array}$ \\
\hline Achillia millefolium & Berguer & Asteraceae & Leaves & $\begin{array}{l}\text { Leaf extract is used to treat pain, inflammation and } \\
\text { gastrointestinal disorders and extract mixed with oats flour is } \\
\text { used to treat snake bites }\end{array}$ \\
\hline Androsac rotundifolia & Uzm posh & Primulaceae & Twigs Roots & $\begin{array}{l}\text { Paste made from tender twigs is used to treat stomach ache and } \\
\text { pertussis. Infusion of the root is used to treat eye poisoning }\end{array}$ \\
\hline Berberis Aristata & Dandleder & Berberidaceae & Bark Roots & $\begin{array}{l}\text { Roots used in piles. Fruit juice is used to relieve toothache. } \\
\text { Powdered bark is used to treat wounds }\end{array}$ \\
\hline Cotoneaster ramicifolia & Luhni & Rosaceae & Whole plant & Fuel/Art and craft, Bark paste is used to treat mild fractures \\
\hline Capsella bursa pastrolis & Kralmond & Brassicaceae & Tender leaves & Leaves are cooked and taken as a vegetable \\
\hline Crategus songarica & Reng Kul & Capridaceae & Fruits & $\begin{array}{l}\text { Fruits used to prepare jams and jellies; fruit extract is used to } \\
\text { treat hypertension }\end{array}$ \\
\hline Cuscuta europea & Kukli Port & Cuscutaceae & Stem & $\begin{array}{l}\text { Decoction of stem is used to treat hair fall and swelling of } \\
\text { testicles }\end{array}$ \\
\hline Colchicum leuteum & Janglikong & Lilliaceae & Bulbs & $\begin{array}{l}\text { Powder of the ground corms mixed with ghee is used to treat } \\
\text { inflammation, and joint pain, stigma of flowers is used as a dye } \\
\text { in local tea-kehwa }\end{array}$ \\
\hline Cynoglossum glochidatum & Cherun & Boraginaceae & Seeds & Seeds are taken to treat impotency and infertility \\
\hline Dipsacus inermis & Wopalhawk & Dipsacaceae & Leaves & Leaf extract is used by women for bathing after delivery \\
\hline Dioscorea deltoids & Krees & Dioscoreaceae & Rhizome & $\begin{array}{l}\text { Dried rhizome is taken orally to treat snake bites and mixed } \\
\text { with milk to treat menstrual cramps. It yields diosgenin - used } \\
\text { as a herbal contraceptive }\end{array}$ \\
\hline Erodium cicutarium & Gardyan & Euphorbiaceae & Whole plant & Whole plant is used as a uterine sedative \\
\hline Fragaria nubicola & Budmewa & Rosaceae & Fruits Rhizome & $\begin{array}{l}\text { Fruits are eaten when ripe. Tea made from rhizome is used by } \\
\text { women to improve lactation }\end{array}$ \\
\hline Galium aparine & Thapeh gass & Rubiaceae & Seeds & Seeds are grinded and used to make coffee \\
\hline
\end{tabular}


Table 1: (Continued)

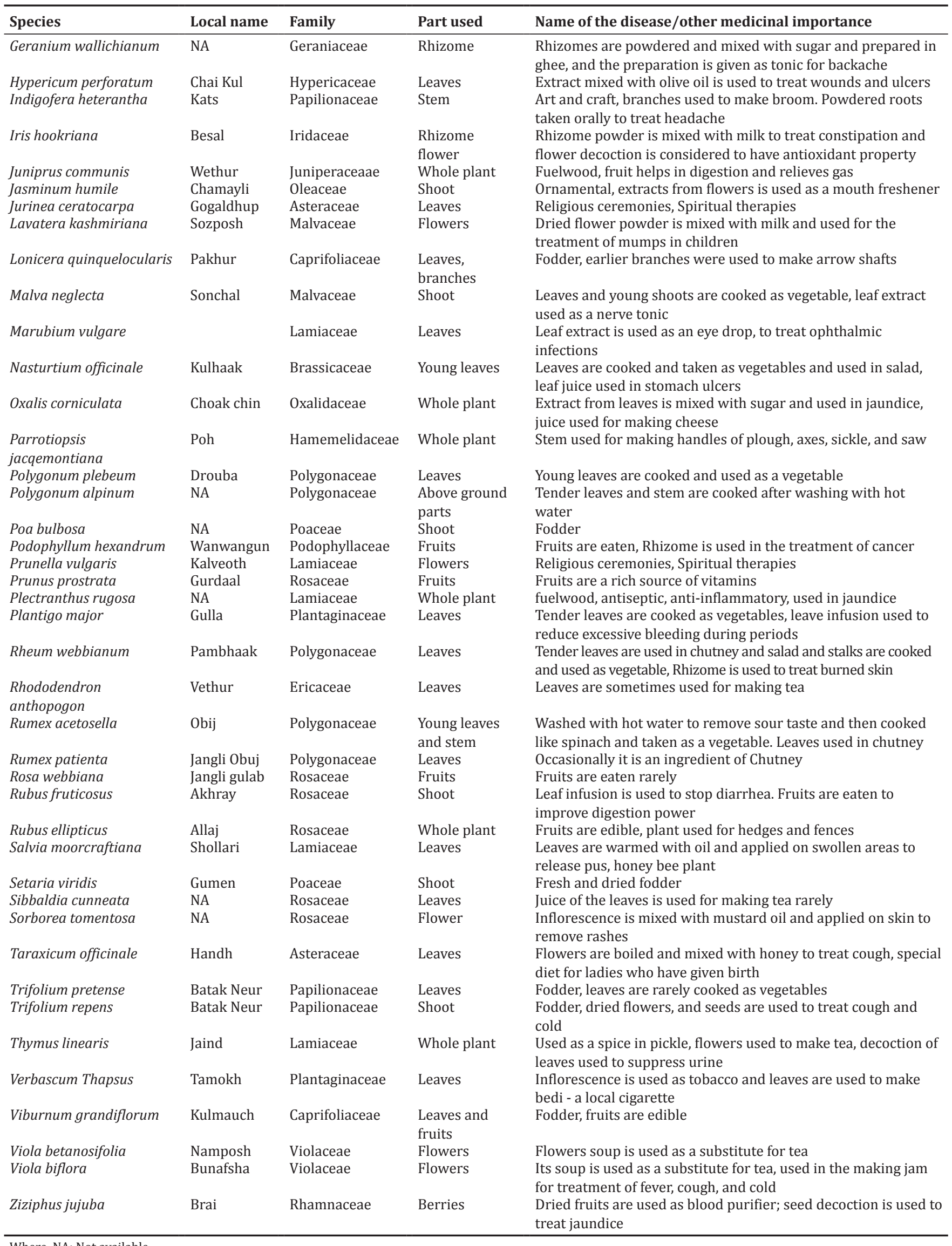

Where, NA: Not available 
Table 2: Ethno-veterinary uses of plants

\begin{tabular}{|c|c|c|c|c|}
\hline Species & Local name & Family & Part used & Medicinal uses \\
\hline Ajuga bracteosa & Jane-adam & Lamiaceae & Ariel parts & $\begin{array}{l}\text { Decoction of leaves is used to stop diarrhea. Powdered } \\
\text { form of leaves added with oil is used to treat wounds and } \\
\text { swelling }\end{array}$ \\
\hline Asparagus filicinus & Halyun & Liliaceae & Seeds & $\begin{array}{l}\text { Water extract with a pinch of sugar is given as infusion for } \\
\text { easy delivery in cattle and goat }\end{array}$ \\
\hline Bergenia ciliata & Zakhm-i-Heyat & Saxifragaceae & Whole plant & $\begin{array}{l}\text { Leaf juice is used against an earache. Roots chewed and } \\
\text { used to clean eyes of livestock }\end{array}$ \\
\hline Geranium wallichianum & Ratan jog & Geraniaceae & Rhizomes leaves & $\begin{array}{l}\text { Rhizome extract boiled in water and flour, cooked in ghee is } \\
\text { used to treat inflammation of hooves. Leaves used to cure } \\
\text { Diarrhea }\end{array}$ \\
\hline Plantigo lenceolata & Gull & Plantaginaceae & Leaves & $\begin{array}{l}\text { Leaves rubbed to skin sting by insects. Fresh leaves are } \\
\text { tightly tied with the muslin cloth to treat fractured bones in } \\
\text { sheep }\end{array}$ \\
\hline Plectranthus rugosa & Solie & Lamiaceae & Leaves & $\begin{array}{l}\text { Dried leaves are given with fodder to treat throat infections } \\
\text { in goats. Leaf extract used to treat snake bites }\end{array}$ \\
\hline Silene vulgare & Takla & Caryophyllaceae & Rhizomes & $\begin{array}{l}\text { Powder of dried rhizome mixed with wheat flour and water } \\
\text { is served to cows for increasing milk production }\end{array}$ \\
\hline Taraxacum officinale & Hund & Asteraceae & Aerial parts & $\begin{array}{l}\text { Extracts from leaves boiled in water are given to cows and } \\
\text { goats after delivery to get rid from general weakness }\end{array}$ \\
\hline Thymus linearis & Ajwain & Lamiaceae & $\begin{array}{l}\text { Seeds } \\
\text { Leaves }\end{array}$ & $\begin{array}{l}\text { Ripe seeds mixed with gour and flour are serves to cattle } \\
\text { to treat common cold and throat infection. Leaves as blood } \\
\text { purifier }\end{array}$ \\
\hline Verbascum Thapsus & Jangli tamookh & Scrophulariaceae & Above ground parts & $\begin{array}{l}\text { The decoction prepared from the aerial parts boiled in water } \\
\text { is mixed with fodder and served to cows and sheep to cure } \\
\text { indigestion and food poisoning. Flower paste applied on } \\
\text { burns }\end{array}$ \\
\hline
\end{tabular}

Where, NA: Not available

Besides poverty, ignorance, unemployment, lack of awareness; human interferences have exerted enormous stresses on vegetation and caused environmental degradation [23]. Due to their economic and medicinal valuability, these plant species are ruthlessly being collected that has threatened the survival of certain plant species such as $P$. hexandrum and S. lappa which are endangered while as I. hookriana, Rheum webbianum, etc., are threatened species. Among medicinal plants Bergenia celiata, $P$. hexandrum, D. deltoids, and $R$. webbianum were once widely used, but now they are restricted in occurrence due to overexploitation for their unique medicinal properties [24].

There is a lack of proper management structure for sustainable collection and utilization of medicinal plants which has put the regeneration potential of these plants at risk and ultimately not only the conservation status of many plants is under threat but also the livelihood of thousands of indigenous people who depend on gathering and sale of medicinal plants [25-29]. Moreover, there is an evidence of declining use of such plants due to loss of interest among young and adult ones and as a result the wealth of knowledge possessed by the older members is hard to transfer among the young minds of these communities which ultimately will lead to fading away of indigenous knowledge associated with these plants [29].

\section{CONCLUSION}

The present protocol was used as a technique to form a base for making useful recommendations to both public and private sectors for rising an awareness at local and country level with an urge to conserve such unique ecosystems. The study concluded that locals are highly dependent on medicinal plants but many plants need to be clinically tested for their secondary metabolites and additional investigation on the ethnobotanical studies of the plants will strive to elucidate specific uses, mode of preparation, and administration for future economic and cultural uses. Further, the intensity and acquisition of such knowledge are fading away among youth due to their changed lifestyle and reliance on chemical medicines. Documentation of such prized knowledge could be useful to formulate popular conservation technique-ethno conservation.

\section{ACKNOWLEDGMENTS}

The authors sincerely acknowledge the respondents, especially the local healers, Vaids, ethnic people, staff of Dachigam National Park, Transhumance, and pastoralists. We are grateful to the Head Department of Environmental Science, BBA Central University, to permit us to carry out the study in the National Park. Special thanks go to Prof A. R Nakshi and Akhtar Hussain Malik, Center of Taxonomy, University of Kashmir for their taxonomical assistance.

\section{AUTHORS' CONTRIBUTIONS}

Arif Yaqoob designed the study, performed the field survey, collected the data and plant species, and contributed in manuscript write up. DP Singh supervised the project, analyzed the data and provided the field equipment and technical support. All authors read and approved the final manuscript.

\section{CONFLICTS OF INTEREST}

The authors have decided that they do not have any conflicts of interest.

\section{REFERENCES}

1. Gaikwad J, Wilson PD, Rangnathan S. Ecological niche modeling of customary medicinal plant species used by Australian aborigines to identify species rich and culturally valuable areas of conservation. Ecol Modell 2011;222:3437-43.

2. Dung NT, Webb EL. Combining local ecological knowledge and quantitative forest surveys to select indicator species for forest condition monitoring in central Veit Nam. Ecol Ind 2008;8:767-70.

3. Dong S, Wen L, Zhu L, Li X. Implication of coupled human implications inn sustainable rangeland ecosystem management in HKN region. Front Earth Sci China 2010;4:1-9.

4. Vacker D, Brink B, Loh J, Baillie JE, Rayers B. Review of multispecies indices for monitoring human impacts on biodiversity. Ecol Indic 2012;17:58-67.

5. Ahmad M, Khan MA, Rashid U, Zaffar M, Arshad M, Sultana S. Quality assurance of herbal drug valerian by chemotaxonomic markers. Afr J Biotechnol 2009;8:1148-54.

6. Madhu CS and Sharada AC. Evaluation of heamagglutination and anti- 
cancer potential from Indian dietary plants. Int J Pharm Pharm Res 2018;10:105-8.

7. Khan SM, Page S, Ahmad H, Shaheen H, Ullah Z, Ahmad M, et al. Medicinal flora and ethnoecological knowledge in the Naran Valley, Western Himalaya, Pakistan. J Ethnobiol Ethnomed 2013;9:4.

8. Shinwari ZK, Gilani SS. Sustainable harvest of medicinal plants at bulashbar nullah, astore (Northern Pakistan). J Ethnopharmacol 2003;84:289-98.

9. Loreau M, Oteng-Yeboah A. Diversity without representation. Nature 2006;422:245

10. Mukherje PK. Exploring green resources for drug development through ethnobotany. In: Chemistry for Green Environment. New Delhi: Narosa Publishing House; 2005. p. 98.

11. Mutenje MJ, Ortmann GF, Ferrer SR. Management of non timber forestry products extraction local institutions, ecological knowledge and market structure in south eastern Zimbabwe. Ecol Econ 2011;70:454-61.

12. Tarrason D, Urrutia JT, Ravera F, Herrera E, Andres P Espelta JM. Con servation status of tropical dry forest ramnants in Nicaragua; do ecological indicators and social perception tally? Biodivers Conserv 2010;19:813-27.

13. Rasul G. The role of the Himalayan mountain systems in food security and agricultural sustainability in South Asia. Int J Rural Manag 2010;6:95-116.

14. Sharma E, Chettri N, Oli KP. Mountain biodiversity con servation and management; a papadigm shift in policies and practicesnin the Hindu Kush-Himalayas. Ecol Res 2010;25:909-23.

15. Khan SM. Plant Communities and Vegetation Ecosystem Services in the Narran Valley, Western Himalaya. Ph. D Tesis. University of Leicester; 2012.

16. Moldan B, Janouskova S, Hak T. How to estimate and measure environmental sustainability: Indicators and targets. Ecol Indic 2011;9:1-5.

17. Akhtar HM, khuroo AA, Dar GH, Khan ZS. Ethmedicinal uses of some plants in Kashmir Himalaya. Ind J Trad Knowl 2011;10:362-6.
18. Khan ZS, khuroo AA, Dar GH. Ethnomedicinal survey of Uri, Kashmir Hmalaya. Ind J Trad. Knowl 2004;3:351.

19. Mishra R. Ecology Work Book. Calcutta: Oxford and IBM Publishing Co.; 1968. p. 244

20. Kannan M, Senthil KT, Rao MV. Ethnobotanical note on the veterinary health care management by Malayali Kalrayan hills. Asian J Pharm Clin Res 2016;9:974-2441.

21. Bhattarai S, Chaudhary RP, Taylor RS. Wild edible plants used by the people of Manang district, central Nepal. Ecol Food Nutr 2009;48:1-20.

22. Sher H, Hussain F. Ethnobotanical evaluation of some plant resources in Northern part of Pakistan. Afr J Biotechnol 2009;8:4066-76.

23. Renuka K, Devi VR, Subramanium SP. Phytochemical screening and evaluation of in vitro antioxidant potential of immature Palmyra palm (Borrassus fillabiliffer Linn.) fruits. Int J Pharm Pharm Res 2018;10:77-83.

24. Zaharai F, Fouzia RF, Abdeliah R. Ethnobotanical study of medicinal plants used in traditional medicine in the province of Sidi Kacem, Morocco Ennacerie. Asian J Pharm Clin Res 2017;10:2455-3891.

25. Sher H, Al Yemeni M. Economically and ecologically important plant communities in high altitude coniferous forest of Malam Jabba, Swat, Pakistan. Saudi J Biol Sci 2011;18:53-61.

26. Sher H, Khan ZD. Resource utilization for economic development and folk medicine among the tribal people; observation from northern parts of Pakistan. Pak J Plant Sci 2006;12:149-62.

27. Khan SM, Page P, Ahmad H, Harper DD. Ethno-ecological importance of plant biodiversity in mountain ecosystems with special emphasis on indicator species of a Himalayan Valley in the northern Pakistan. Ecol Indic 2014;37:175-85

28. Yaqoob A, Singh DP, Yunus M, Bhat GA (2017) Phytotherapeutic and Ethno-botanical Importance of Plant Biodiversity of Dachigam National Park, Kashmir. Am J Ethnomed; 4; 2:12.

29. Bussmann RW, Sharon D. Traditional medicinal plant uses in Northern Peru: Tracking two thousand years of healing culture. J Ethnobiol Ethnomed 2006;2:47. 